\title{
Ancient Egyptian Gold Refining
}

\section{A REPRODUCTION OF EARLY TECHNIQUES}

\author{
J. H. F. Notton
}

Johnson Matthey \& Co Limited, London

The technique of smelting mined gold ore concentrates reported by Diodorus Siculus as being used in Egypt in the Second Century B.C. has been simulated in the laboratory. A considerable degree of refining was found, comparable with that yielded by the medieval process of cementation with salt, and with a negligible loss of gold.

The review by T. G. H. James of the British Museum in an earlier volume of this journal (1) has shown most vividly how skilled the Ancient Egyptians were in methods of fabricating gold. We know also of the large amounts of gold that must have come from the alluvial spoil heaps and quarries which still bear witness to their activities. As with many things in those days, religious mystique extended to gold and its uses, while the use to which any gold that was discovered was put was governed by Royal decree. The processes of winning and working the metal were similarly delegated by the King to the priesthood of the god Ptah. The god himself was given the attribute of "Master of the gold smelters and goldsmiths", and his temple at Memphis was the "Goldsmithy".

This temple was visited by the alchemist Zosimos in the Third Century A.D., and he found that the processes and equipment were comparable with his own knowledge and practices. Zosimos also records some of the quaint titles given to the artisan priests, such as "He who knows the secrets of the goldsmiths" and "Great wielder of the hammer".

Unfortunately for posterity, very little written material describing their processes survives, even if the techniques were ever thought worthy of recording.

Until new evidence is forthcoming much speculation will continue regarding the earliest date at which refining methods were developed in Egypt. The date now generally accepted is about 500 B.C., although some authorities claim 2000 B.C. as possible. The reasoning in both cases is based on the chemical analysis data for various datable gold objects. Samples having a greater degree of fineness than can be expected in natural gold can be taken as an indication of the use of refining techniques, while the occurrence of unusual alloys might also be taken as evidence. Unfortunately this method is open to certain difficulties. Ancient Egyptian gold articles are not as common as might be generally expected and are often not available for analysis from crucial time periods. There is also a natural reluctance to sacrifice or deface valuable and beautiful objects to satisfy the wishes of the archaeologist.

The effect of the introduction of refined domestic metal might be obscured by the Royal monopoly which ensured, officially or unofficially, that metal from previous Dynasties was recycled. In addition large amounts of gold must have been imported, by trade, plunder or tribute from other nations. Both of these sources introduce metal of different degrees of alloying or purity to any time period and even when refining was an established process it is possible that such metal was re-used without refining.

A final factor that could obscure the transition to the use of a refined product is a hypothetical period in which partial refining only was achieved.

As far as Europe is concerned some very valuable conclusions relating to sources of gold and trade routes have arisen from a programme of spectrographic analysis of prehistoric gold objects. This work, which was reported by Dr. Axel Hartmann (2) of Mainz Museum, bases its conclusions on the premise that no refining was practised in Europe until Roman times. The method is based on a study of all the minor and trace constituents of the goids examined. It is to be hoped that eventually a similar project can be carried out for Egyptian metal.

Another analytical approach to gold alloys, in this case non-destructive, is the use of specific gravity measurements to detect composition changes. This technique has recently been used by Professor J. F. Healy to confirm or add to the evidence of diestudy in establishing sequences in Greek "white gold" and electrum coins belonging to the fifth and fourth centuries B.C. (3). The minting of some of these coins, jointly by the Island cities of Mytilene and Phokaia, was controlled by a treaty expressed in terms which show that the coin alloy used was 


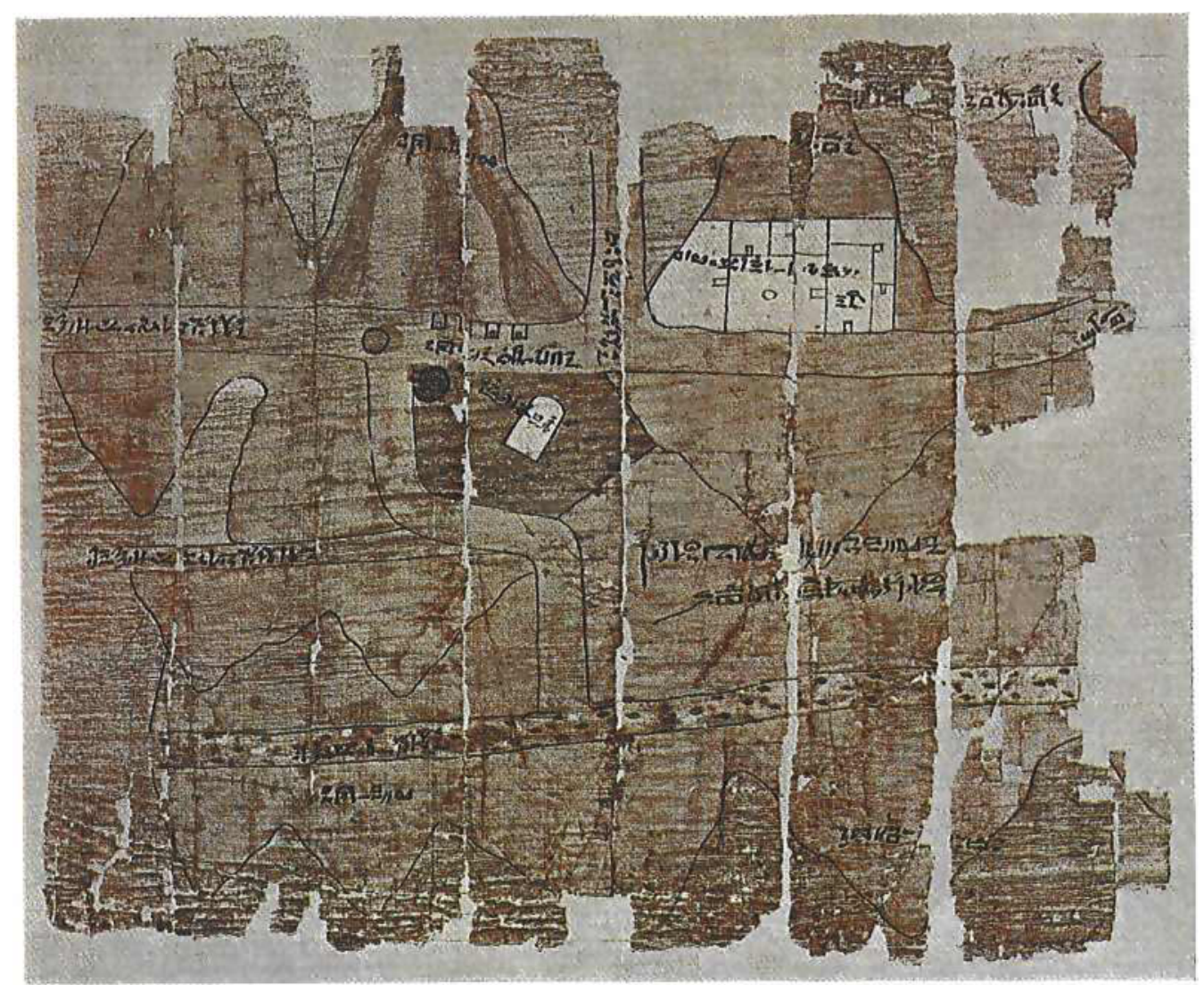

Photograph by courtesy of Dr. Silvio Curto, Egyptian Museum, Turin

Thought to be the oldest map in the world, a papyrus dating from about 1100 B.C. and now in the Turin museum shows a gold-bearing region in the Eastern Desert of Egypt. The area shown is in the Wadi Hammamat, between the modern towns of Quena and Qoseir. A network of roads intersects a mountainous region, shown in pink, and inscriptions indicate where gold is located in individual mountains. Near the centre of the map is a white stela bearing the name of King Seti I, and a little to the left is a well which is identifiable as the modern Bir el-Hammamat. The white area near the top right is the temple of the god Amon and at the side of the road near the well are four buildings, the inscription reading "the houses where they wash the gold" ${ }_{3}$ The map is orientated with south at the top and the roads leading off to the left of this fragment eventually reach the Red Sea at Qoseir.

quality controlled and could be assayed for gold. A recent metallurgical examination (4) of one of these coins stimulated interest in assay and refining methods available to the coiners. Of particular interest in this context was the discovery of a gold enriched layer on the surface of the coin, over 70 per cent gold being found in places compared to about 35 per cent for the bulk metal. It is not known whether this is a result of natural weathering processes where the coin was buried or of the deliberate application of a process similar to that discussed later to improve the colour of the coin.

In fact, some indications of Egyptian mining and refining techniques are available to us, but these are of late date when compared with the thousands of years in which gold was used in the Nile valley.
An early pictorial glimpse is given by a papyrus in the Turin museum, an original document believed to date from about 1100 B.C. in the Twentieth Dynasty. It is considered to be a map of a gold bearing region in the Eastern desert of Egypt and if so it is probably the oldest map in the world $(5,6)$. The region depicted is thought to be in the Wadi Hammamat, lying between the present-day towns of Quena and Qoseir. Portions of the Papyrus survive-it totals over nine feet in length-and the part best preserved is the one end illustrated above. The areas coloured pink with wavy lines on the map are mountainous areas and inscriptions on some of them indicate where gold is to be found. As the map is reproduced here the inscriptions are the right way up but north is then to the bottom of the map. The roads which lead off to the right of the fragment are 
In the latter part of the Second Century BC the Greek geographer Agatharchides of Cnidus visited Egypt and described among other things the working of the gold mines and the methods of extraction employed. Diodorus Siculus also travelled in Egypt in about $60 \mathrm{BC}$, but in his Bibliotheca Historica drew largely upon the account given by Agatharchides of the working of gold. His description is reproduced below.

"At the extremity of Egypt and in the contiguous territory of both Arabia and Ethiopia there lies a region which contains many large gold mines, where the gold is secured in great quantities with much suffering and at great expense. For the earth is naturally black and contains seams and veins of a marble which is unusually white and in brilliancy surpasses everything else which shines brightly by its nature, and here the overseers of the labour in the mines recover the gold with the aid of a multitude of workers. For the kings of Egypt gather together and condemn to the mining of the gold such as have been found guilty of some crime and captives of war, as well as those who have been accused unjustly and thrown into prison because of their anger, and not only such persons but occasionally all their relatives as well, by this means not only inflicting punishment upon those found guilty but also securing at the same time great revenues from their labours. And those who have been condemned in this way-and they are a great multitude and are all bound in chains-work at their task unceasingly both by day and throughout the entire night, enjoying no respite and being carefully cut off from any means of escape; since guards of foreign soldiers who speak a language different from theirs stand watch over them, so that not a man, either by conversation or by some contact of a friendly nature, is able to corrupt one of his keepers. The gold bearing earth which is hardest they first burn with a hot fire, and when they have crumbled it in this way they continue the working of it by hand; and the soft rock which can yield to moderate effort is crushed with a sledge by myriads of unfortunate wretches. And the entire operations are in charge of a skilled worker who distinguishes the stone and points it out to the labourers; and of those who are assigned to this unfortunate task the physically strongest break the quartz-rock with iron hammers, applying no skill to the task, but only force, and cutting tunnels through the stone, not in a straight line but wherever the seam of gleaming rock may lead. Now these men, working in darkness as they do because of the bending and winding of the passages, carry lamps bound on their foreheads; and since much of the time they change the position of their bodies to follow the particular character of the stone they throw the blocks, as they cut them out, on the ground; and at this task they labour without ceasing beneath the sternness and blows of an overseer.
"The boys there who have not yet come to maturity, entering through the tunnels into the galleries formed by the removal of the rock, laboriously gather up the rock as it is cast down piece by piece and carry it out into the open to the place outside the entrance. Then those who are above thirty years of age take this quarried stone from them and with iron pestles pound a specified amount of it in stone mortars, until they have worked it down to the size of a vetch. Thereupon the women and older men receive from them the rock of this size and cast it into mills of which a number stand there in a row, and taking their places in groups of two or three at the spoke or handle of each mill they grind it until they have worked down the amount given them until it has the consistency of the finest flour.

"In the last steps the skilled workmen receive the stone which has been ground to powder and take it off for its complete and final working; for they rub the marble which has been worked down upon a broad board which is slightly inclined, pouring water over it all the while; whereupon the earthy matter in it, melted away by the action of the water, runs down the in clined board, while that which contains the gold remains on the wood because of its weight. And repeating this a number of times, they first of all rub it gently with their hands, and then lightly pressing it with sponges of loose texture they remove in this way whatever is porous and earthy, until there remains only the pure gold-dust.

"Then at last other skilled workmen take away what has been recovered and put it by fixed measure and weight into earthen jars, mixing with it a lump of lead proportionate to the mass, lumps of salt and a little tin, and adding thereto. barley bran; thereupon they put on it a closefitting lid, and smearing it over carefully with mud they bake it in a kiln for five successive days and as many nights; and at the end of this period, when they have let the jars cool off, of the other matter they find no remains in the jars, but the gold they recover in pure form, there being but little waste. This working of the gold, as it is carried on at the farthermost borders of Egypt, is effected through all the extensive labours here described; for Nature herself, in my opinion, makes it clear that whereas the production of gold is laborious, the guarding of it is difficult, the zest for it is very great, and that its use is halfway between pleasure and pain." 


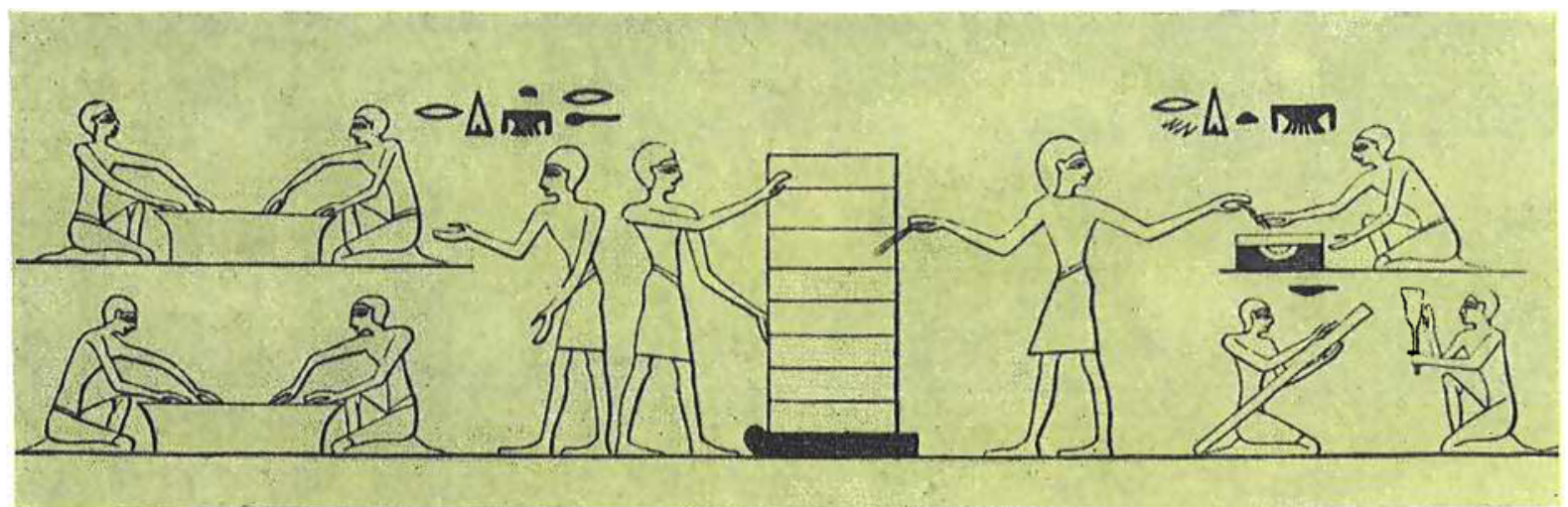

In this drawing of a sculptured relief in the tomb of Baqt at Beni Hassan, dating from about 2000 B.C., the processes described by Diodorus Sieulus are almost exactly represented. On the left the gold ore is being washed; the standing figures in the centre appear to be working with a gravity concentrating table, while at the upper right of the scene the concentrates are being put into the earthen jar with a close-fitting lid for the refining operation

continued on the other portions of the map and ultimately lead to the Valley of the Nile.

A second glimpse comes from the account of Agatharchides' travels in Egypt in the second century B.C. as related by Diodorus Siculus. This is a remarkable piece of journalism, worth quoting in its entirety, and it is reproduced on the opposite page in the translation by C. H. Oldfather (7).

Traces of many of the mining and extraction processes described by Agatharchides have been found by archaeologists in the gold-bearing regions of Egypt. The large number of mine sites that have been identified is shown on the map, based upon a sketch map by J. Vercoutter of the Sudan Antiquities Service in a paper on "The Gold of Kush" (8). The Wadi Hammamat, shown in the Turin papyrus, is to be seen at the top of the map.

One of the problems in a largely waterless country would be the obtaining of sufficient water to wash the ore. Agatharchides describes all the stages of the extraction process from rock to refined metal as taking place conveniently at the one site, but Vercoutter and other archaeologists have shown that this was not always the case and that some enigmatic structures found near the Nile were most probably gold washing installations. These structures generally consisted of

The gold bearing regions of Ancient Egypt, showing the location of identified mining sites, based on a sketch map by J. Vercoutter. The Wadi Hammamat of the Turin papyrus is to be seen at the top of the map flat, sloping rock surfaces leading downwards through channels to one or more pits or basins. Clearly the sloping surface could have been used as a gravity separation table, with the basins as settling tanks for the slurry. Thus, as far as the remoter regions are concerned it seems likely that the ore was sometimes carried to the river bank for washing and refining. On the other hand the sculptured relief at Beni Hassan, part of which is illustrated above, seems to show all the processes grouped in one place.

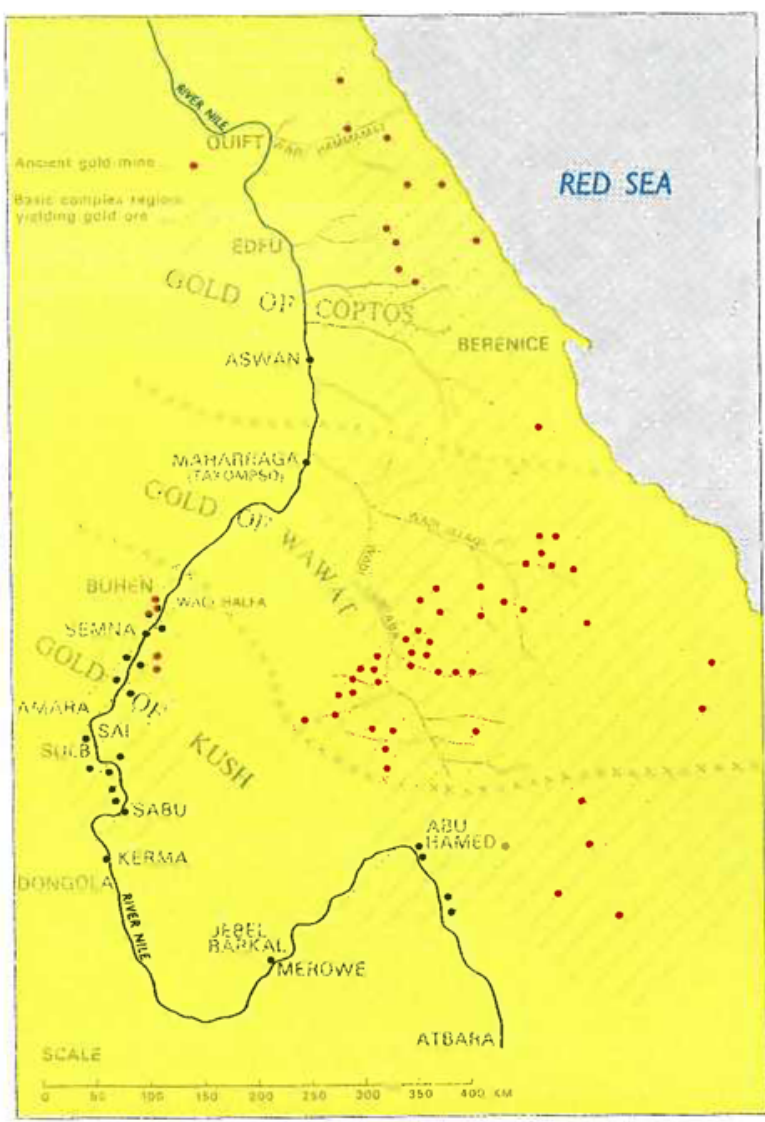


Egyptian gold took two forms, dust or powder from alluvial workings and ring-shaped ingots cast from the smelted gold produced in the mines. This wall painting from the tomb of Sobkhotpe, a high official buried at Thebes in about 1420 B.C., shows the presentation of tribute from the outlying regions of the Egyptian empire. Negroes are bearing trays of gold dust in small bags of hide and carrying chains of the ring ingots

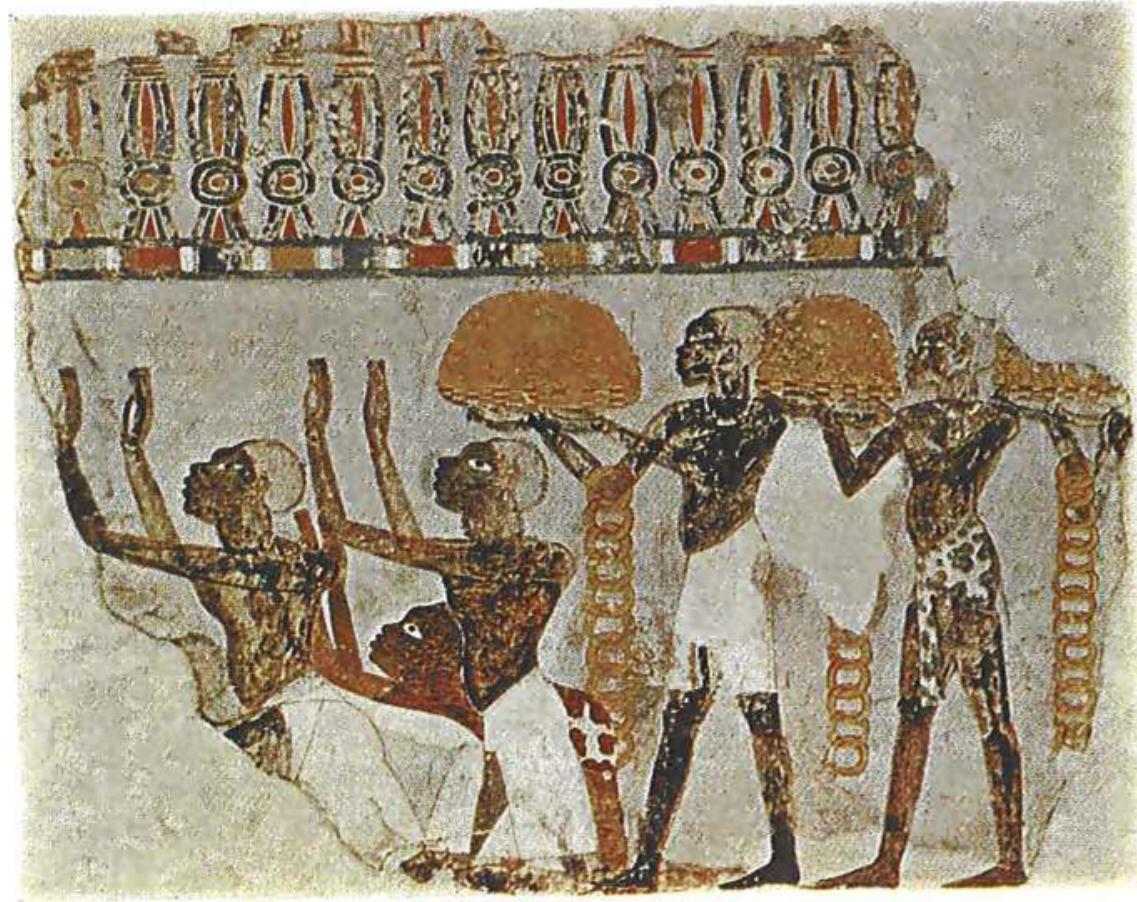

The last paragraph of the quotation from Agatharchides contains the only detailed account of what may be gold refining to predate Pliny (9) who, in the first century A.D. gives a recognisable account of the cementation process using salt which was to become developed to its greatest usefulness in medieval times. In this process the impure gold, in the form of sheet or grain, was placed in a crucible in intimate contact with a mixture of salt and brickdust and heated in a controlled furnace. The silver and base metals present in the gold were either volatilised or absorbed in the brickdust, leaving pure gold which was readily separated from the brickdust "cement" by washing.

\section{Simulation of Cementation}

Some authorities consider that Agatharchides is also describing the cementation process and others that only cupellation is intended. It may be that the description is a mixture of both processes.

There is a lack of evidence in the present-day literature that the process observed by Agatharchides
In the reproduction of the medieval process of gold refining by cementation with salt and brick dust a gold alloy was used containing both copper and silver with a gold content of 37.5 per cent. This process removed all the copper and sufficient silver to raise the gold content to 93 per cent. The salt and brick dust mixture are shown before and after use, the blue glassy slag formed being clearly visible. The scorifier has been discoloured by the copper in the alloy

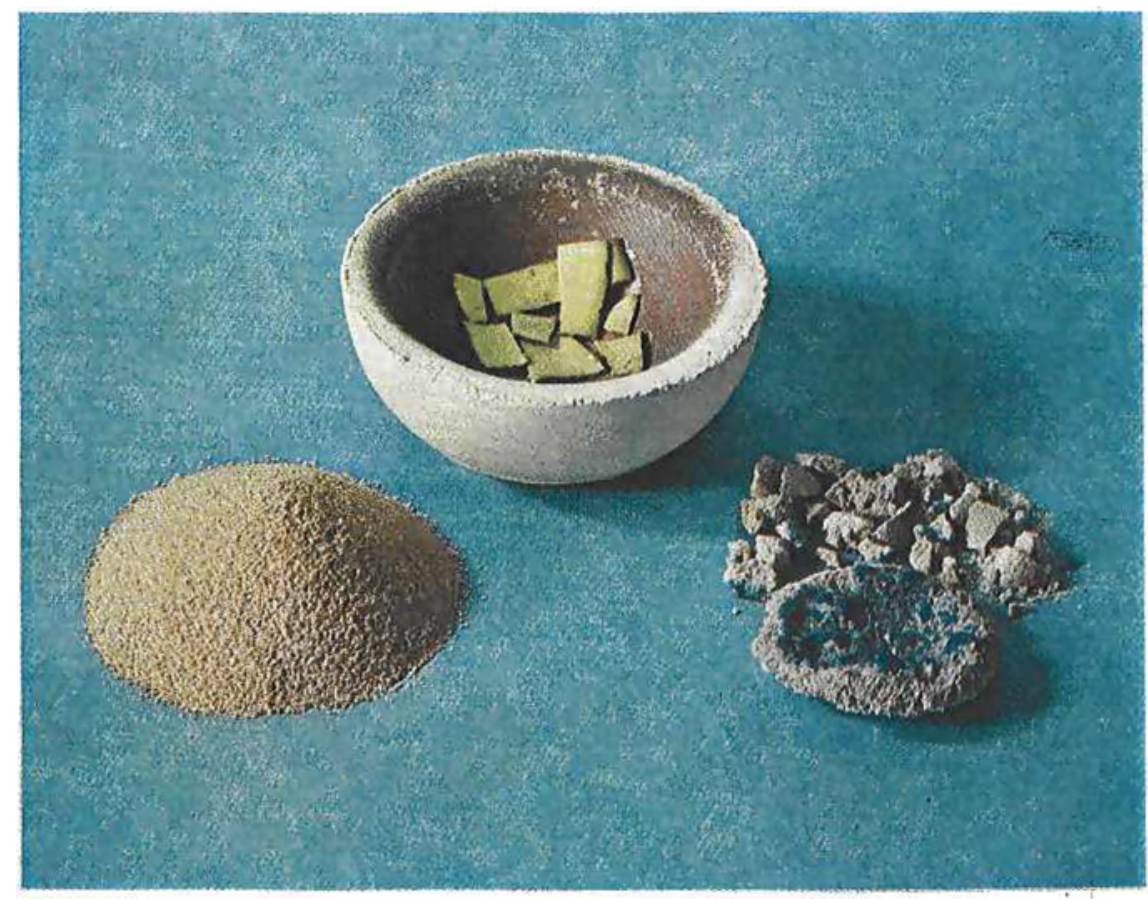


The simulation of the Egyptian process of gold refining involved sealing up portions of the same low content alloy with salt in a sillimanite pot and heating at $800^{\circ} \mathrm{C}$ until fuming ceased. This shows the charge as prepared for the experiment

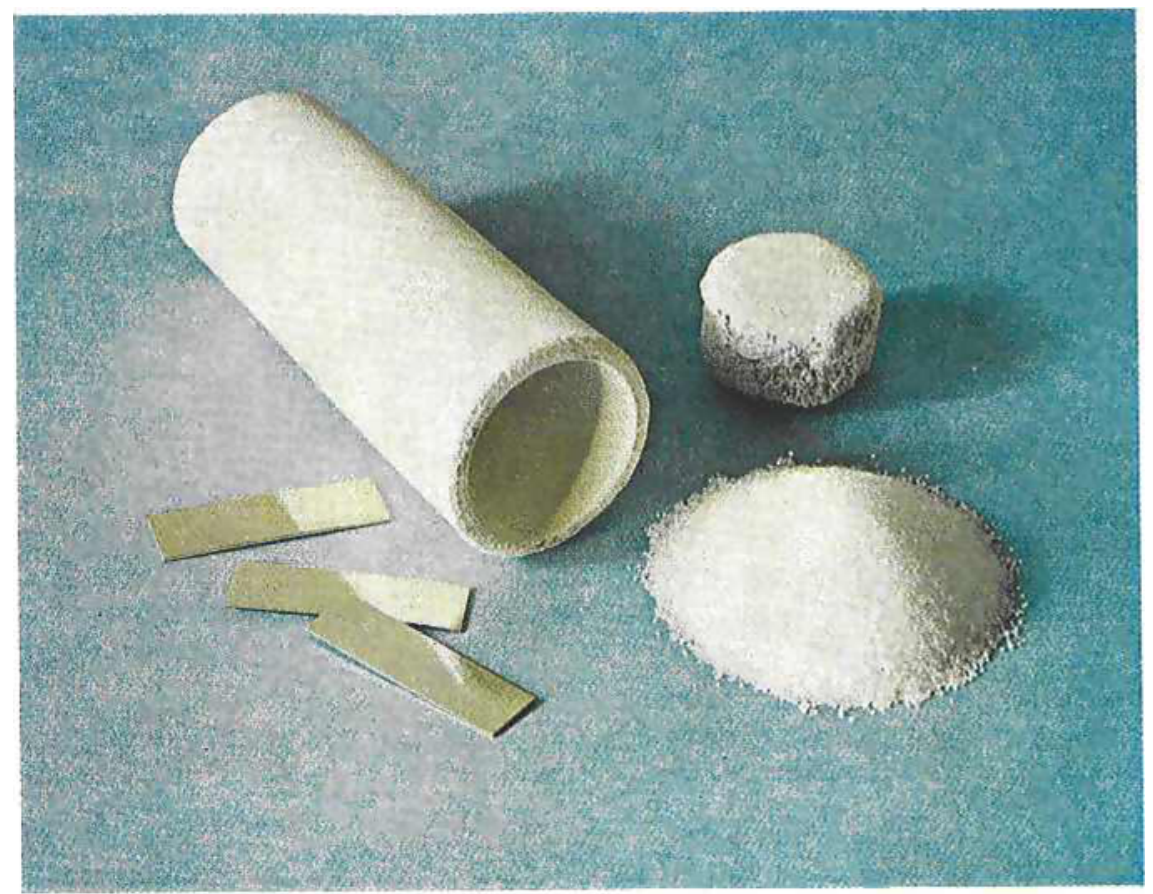

has ever been repeated under modern conditions. Accordingly the author carried out some experiments designed to test the process and to compare it with the method of cementation with salt.

For the cementation process small portions of a white gold alloy sheet containing copper and silver were used. These were placed on a scorifier and buried under a small heap of a mixture of salt and brick dust and heated at $800^{\circ} \mathrm{C}$ for some hours until no more salt fumes were evolved. This procedure was found to remove all of the copper and sufficient silver to raise the gold content of the residue from a starting value of 37.5 per cent to 93 per cent. The result of a typical test is illustrated on page 54 . The refined gold is shown on the scorifier which has been stained brown by copper.

\section{Reproduction of the \\ Egyptian Refining Process}

Since the active principle of both methods appears to be the salt, the tests of the Egyptian process were commenced by sealing up portions of the gold alloy

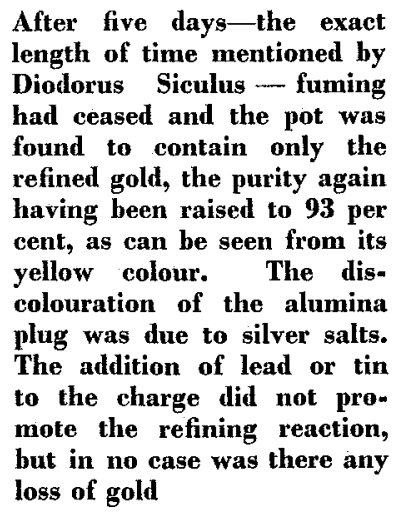

After five days-the exact length of time mentioned by Diodorus Siculus - fuming had ceased and the pot was found to contain only the refined gold, the purity again having been raised to 93 per cent, as can be seen from its yellow colour. The discolouration of the alumina plug was due to silver salts. The addition of lead or tin to the charge did not promote the refining reaction, but in no case was there any loss of gold

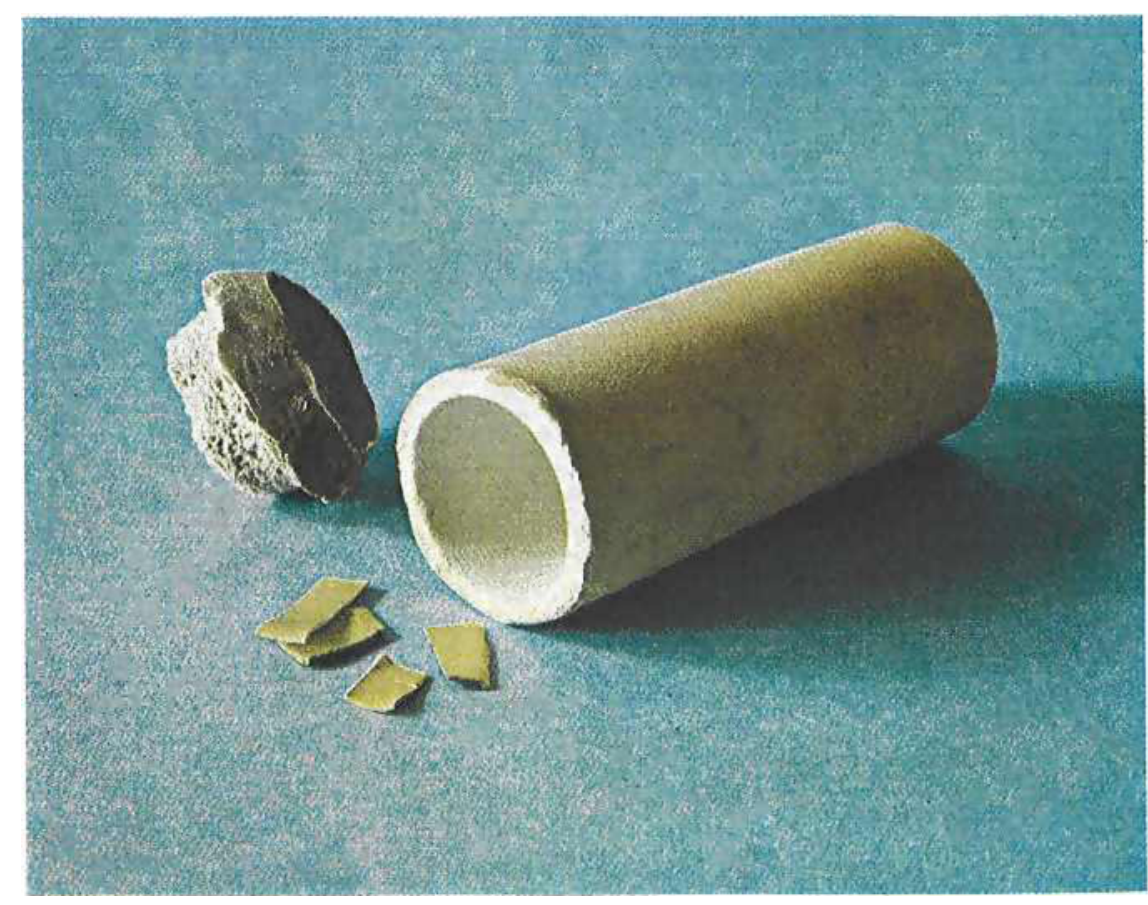


with the salt in a commercial sillimanite pot using an alumina cement. This pot was also heated at $800^{\circ} \mathrm{C}$ until fuming ceased. By a very strange coincidence this was found to be after five days-exactly as described by Diodorus Siculus-but since tests with other sizes and types of pots were not made this cannot be claimed as anything other than a coincidence at present. The experiment was then repeated with the addition to the salt and gold alloy of one or more of the other ingredients mentioned. Another translation of the Greek text seems to indicate that the bran refers to the use of a chaff fire to heat the pots, but for these tests it was assumed to be present as a reducing agent, and was added as charcoal. The test with salt alone was very successful since the only residue in the pot was the refined metal as required by the text. Again the gold content of the metal had been raised to over 93 per cent.

The illustrations show the pot and the ingredients for this test, while the lower picture on page 55 shows the refined metal and the discoloration of the plug which in this case appeared to be due to silver salts. Considerable amounts of silver were recovered from crystalline deposits of sublimed salt in the cooler parts of the furnace.

With the addition of charcoal to the mixture it was found that the gold content of the residue was raised to only 80 per cent.

The addition of lead or tin reduced the gold content of the refined product still further. In the case of tin a residue of tin oxide was present in the pot which appeared to have prevented the reaction going to completion since the gold still contained tin. With lead present a glassy slag formed which did not soak into the pot and again prevented complete reaction. However, in all the tests, including those using cementation, no gold was lost.

Thus, so long as salt is used by itself, the method described by Agatharchides works as well as cementation to produce refined gold. It is conceivable that with contemporary pots the process would work better. If such pots were also capable of soaking up the lead oxide slag then it is possible to argue that the lead was added as a flux to remove the final traces of siliceous gangue which must have remained in the gold concentrate.

On the basis of the present tests it is not possible to account for the inclusion of tin in the recipe, unless it was deliberately included to confuse Agatharchides, possibly in an attempt to keep the secret of the process.

The cementation process is known to have been used repetitively to obtain a really pure product. Repetition may be necessary for the Egyptian method, but no particular effort was made to optimise the conditions used in this short series of tests.

It would be pleasant to feel that these simple experiments would be of direct use in establishing when gold refining was invented in Ancient Egypt, although possibly their only real result is a comment on the powers of observation and description displayed by Agatharchides the Geographer as reported by Diodorus Siculus.

\section{Acknowledgements}

The author wishes to thank $\mathrm{Mr} T$. G. H. James and $\mathrm{Mr}$ Peter Clayton of the British Museum for assistance with illustrations, and Professor J. F. Healy of Royal Holloway College, London, for inspiration and advice.

\section{References}

1 T. G. H. James, Gold Bulletin, 1972, 5, (2), 38

2 A. Hartmann and E. Sangmeister, Angew. Chem., 1972, 84, (14), 668. See also Gold Bulletin, 1973, 6, (2), 51

3 J. F. Healy, Numismatic Chronicle, Seventh Series, 1971 , 9,31

4 J. F. Healy and A. S. Darling, Nature, 1971, 231, (5303), 443, and unpublished work

5 Ernesto Scammuzzi, "Egyptian Art in the Turin Museum", H. N. Abrams Inc., Plate 88

6 A. H. Gardiner, Cairo Scientific F., 1914, 8, 41

7 Diodorus Siculus, Book III, Chapters 12 to 14 ; C. H. Oldfather translation, Loeb Classical Library, 1935, 115-123

8 I. Vercoutter, Kush, (F. Sudan Antiquities Service), 1959 7, 120

9 Pliny, Historia Naturalis, XXXIII, 25

COLD is the only thing that loses no substance by the action of fire. Indeed $\checkmark$ as a matter of fact it improves in quality the more often it is fired, and fire serves as a test of its goodness... . Moreover in steady resistance to the overpowering effect of the juices of salt and vinegar it surpasses all things, and over and above that it can be spun into thread and woven into a fabric like wool.

GAIUS PLINIUS SECUNDUS

Rome, A.D. 77

(Pliny the Elder)

Natural History 